\title{
Geomechanical issues in the development of the Udachnaya diamondiferous pipe
}

\author{
K.A. Anisimov \\ Postgraduate student, Saint-Petersburg mining university, Saint-Petersburg, Russian Federation \\ D.G. Sokol \\ Postgraduate student, Saint-Petersburg mining university, Saint-Petersburg, Russian Federation \\ V.P. Zubov \\ Professor, Saint-Petersburg mining university, Saint-Petersburg, Russian Federation
}

\begin{abstract}
The data of researches and observations of the geological settings on the Udachnaya kimberlite pipe since the commissioning of the underground mine was considered in this article. The main geomechanical parameters that complicate mining were studied; recommendations on the future researches were given.
\end{abstract}

\section{INTRODUCTION}

Nowadays, Udachny Mining and Processing Division (MPD) develops two primary diamond deposits: Udachnaya and Zarnitsa, as well as Dellyuvialnaya and Ruchey Piropovy placer deposits of the Udachnaya kimberlite pipe (Brief report by independent experts on the reserves and resources of diamond deposits of the ALROSA group of companies, 2018).

The Udachnaya kimberlite pipe has a crucial meaning to the development of the Udachny MPD. This deposit is located in the Daldino Alakit diamondiferous area, close to the city of the same name. The pipe can be traced as a single ore body from the surface to a depth of $250 \mathrm{~m}$. Downstream it splits into two independent ore bodies - East (EOB) and West (WOB), separated by a block of host secondary rocks of the upper-Cambrian period (Figure 1) (Drozdov, 2015).

For a long time, the pipe had been mined as an open-pit. Udachny open-pit was put into production in 1971, and it has been functioning for over 40 years. Open-pit mining was completed in 2016; the depth of the open-pit was 640 meters at the time of the completion.

The Udachny underground mine was put into production in 2014. The development of the ore reserves, which lie below the bottom of the open-pit with absolute elevation of $-320 \mathrm{~m}$, is provided by three vertical shafts located south of the pit: cage shaft, air shaft and skip shaft. Moreover, main opening adits are driven into the sides of the open-pit at $-170 \mathrm{~m}$ and $-290 \mathrm{~m}$ levels, and they are connected with West and East airway crosscuts at $-380 \mathrm{~m}$ level through the runaway No.1 (Nikitin, 2017).

\section{RESEARCH}

The development of the underground reserves of the Udachnaya pipe was started at the level of 260/-320 m WOB and EOB. There were ore reserves left in the pit sides on these levels. Mining method, which was applied to develop these reserves: sublevel caving with the side ore drawing, showed excellent results providing a sufficiently high volume of ore mass production with low rates of loss and dilution. More than half of the ore mined on the pit sides was dumped at the 


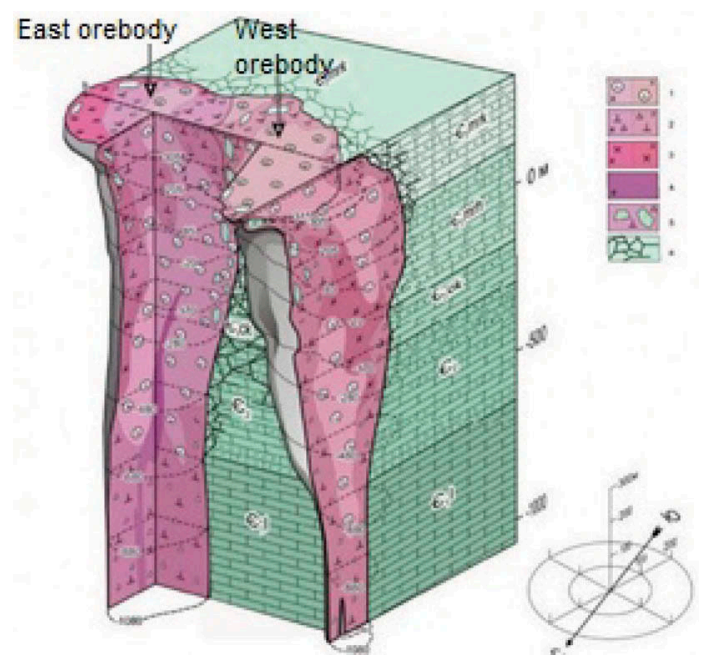

Figure 1. Geological structure of the kimberlite pipe (G.S. Von der Flaas representation). 1 - autolithic kimberlite breccia (phase III); 2 - kimberlite breccia (II); 3 - kimberlite breccia of the massive structure (phase I); 4 - porphyritic kimberlite (phase IV); 5 - kimberlite breccia with large xenoliths of host rocks; 6 - crushing area of host rocks.

bottom of the pit; some of the reserves were transported to the Processing Plant No. 12 (PP No. 12) in the city of Udachny. The bottom of the pit at $-320 \mathrm{~m}$ and $-365 \mathrm{~m}$ levels was also destroyed to create a movable and friable safety cushion. This ore safety cushion is a three-dimensional moving rock mass with a designed height of up to 65 meters, which provides a seal between the underground mining and the open-pit space. The safety cushion is going to be slowly lowered following a decrease in the level of mining operations in accordance with the designed mining method of the kimberlite pipe (Drozdov, 2015; Piven', 2011).

A high-performance method of combined shrinkage stoping and caving with one-stage stoping and areal ore drawing is implemented (Figure 2) to develop primary reserves, located below the bottom of the pit up to the level of $600 \mathrm{~m}$. This mining method is unique for diamondiferous deposits of the Far North, since earlier such methods had not been used in such difficult climatic conditions. There has also been a significant change in technology for creating a safety cushion between the open pit and the underground mine. Traditionally, the bottom of the pit is either left forming a pillar of kimberlite rocks of the sufficient thickness, or artificial filling mass is made (Aikhal, Mir, Internatsionalny mines), when designing the development of a diamondiferous deposit. The movable and friable ore safety cushion was designed at the Udachny mine. Lowperformance cut-and-fill mining methods are commonly implemented in the fields of the Far North. These methods allow reducing the negative climate impact on the underground mining, reducing the influence of hydrological parameters and increasing the safety of personnel in mining zones (Kovalenko, Tishkov, 2017). The method of combined shrinkage stoping and caving with a friable safety cushion is used in the countries of the African continent (Finsh and Kimberly mines). This method has a higher productivity rate: it was possible to achieve and maintain the mine's productivity at the same level as in open-pits with the introduction of these mining methods in the mines of South Africa at a cost-per-ton of ore much less than that of the cut-and-fill mining methods (Chadwick, 2012).

Diesel load-haul-dumpers and self-propelled drillers are used at the drawing-off levels. It is planned to use electrical equipment on the main haulage levels, in particular, a belt conveyer is used on the main haulage level at the elevation of $-480 \mathrm{~m}$, ore gets onto it from an underground crushing facility. The projected production rate for 2018 was 2.7 million tons. The mine was supposed to reach full production capacity by 2019 , ensuring the production of 


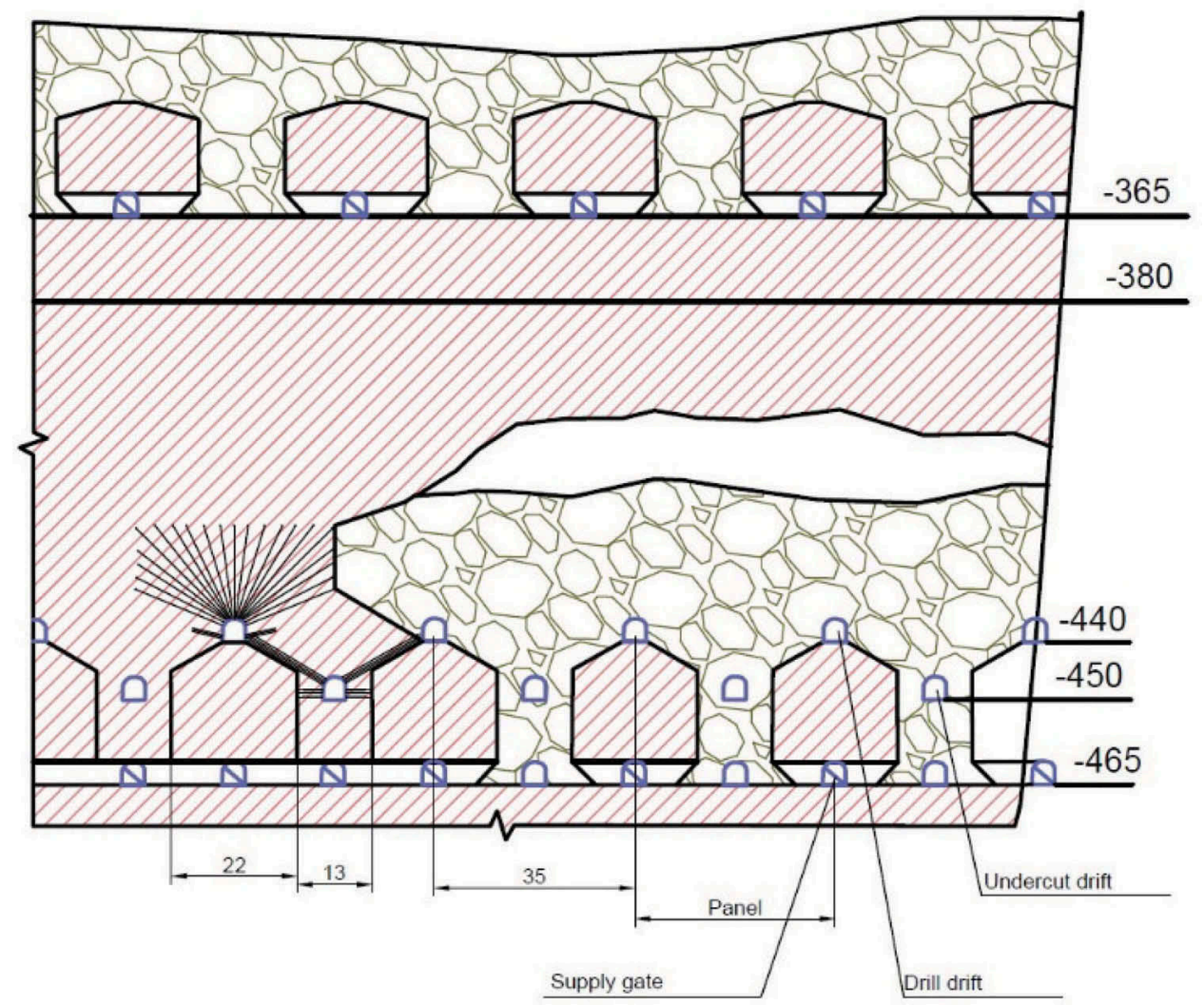

Figure 2. Part of the combined shrinkage stoping and caving method; the lay out of the workings on the $-450 \mathrm{~m}$ level (undercutting level).

4.0 million tons of ore annually, however, as for the III quarter of 2019, 1836 thousand tons of ore were mined, ensuring that the plan was not fulfilled almost twice (The quarterly report of ALROSA PJSC for the 3rd quarter of 2019, 2019).

The development of the Udachnaya kimberlite pipe is extremely difficult, climatic and geological conditions have a significant impact on the development process. The main factors that have a critical value for the operation of the underground mine are the following:

- Kimberlite pipe is located in the extreme climatic conditions of the Far North, almost at the level of the Arctic Circle. The pipe is located in the permafrost area with a large frost depth of rocks. Sharply continental climate is described by large daily temperature swings, which negatively affect the stability of rock masses (Balek, Sashurin, 2016);

- Water cut is distributed highly uneven in the developed rock masses, the geological structure of the pipe and surrounding rocks is formed without natural aquicludes, which leads to the free promotion of aggressive and high-salinity brines with a total salinity of up to $400 \mathrm{~g} / \mathrm{l}$ (Balek, Sashurin, 2016);

- The rock mass, which surrounds the pipe, is extremely disturbed, host rocks and kimberlite rocks have a network of deep (up to 50 meters) fractures and various disturbances located randomly. Cases of groundwater breakthroughs in mines due to penetration of fractures during drilling wells, etc., were recorded (Balek, Efremov, 2016; Kovalenko, Tishkov, 2016);

- Ore and rock masses have low stability; the dependence of the kimberlite's stability on the time of its contact with the mine's air has been established: it drops significantly over the year, increasing the cost of fastening and maintaining mine workings (Bokiy, Zoteev, 
Pul, 2019). The most disturbed mass is the mass of waste rocks in the space between the WOB and EOB; it contains many disturbances and manifestations of fracturing;

- Many zones of increased fracturing, hazardous places of low coherence, caused by various hydro-geomechanical, geomechanical and other factors were particularly highlighted. Special timbering plans are often designed for such zones and there is special monitoring of the state of the underground mines (according to PJSC ALROSA);

- The mine is hazardous in terms of gas emission; there have been cases of oil and gas occurrences during mining on the levels of $-260 \mathrm{~m} /-380 \mathrm{~m}$ that negatively affect the development of the field (Brief report by independent experts on the reserves and resources of diamond deposits of the ALROSA group of companies, 2018).

The development of the Udachnaya kimberlite pipe is a big challenge for Russian science, forming a certain number of extremely unique and often advanced solutions. The Yakutniproalmaz Institute was initially involved in the development of all design decisions; part of the work was carried out in Saint-Petersburg at the Institute GIPRONIKEL LLC, the Institute of Mining of Ural Branch of RAS carried out the research work and technical solutions. Therefore, technological parameters of the development process of the Udachnaya kimberlite pipe have been studied for a long time taking into consideration the wishes of the direct customer PJSC ALROSA.

However, the following negative factors that affect mining process were noted in the first few years of the mine's operations:

1. A methane-air mixture exploded during the driving of the runaway due to the strong gas contamination of the mine and insufficient ventilation. Gas manifestations were repeatedly recorded in the mine atmosphere during further mining operations, there were also oil products ignitions after the production cycle of the blast hole drilling (according to the regional department of the Russian Ministry of Emergency Situations).

These negative factors are caused by the content of petroleum bitumen in the host rocks. Its content on different mining depth varies from 0.6 to $2.35 \%$, and lower in the section (level $-480 \mathrm{~m} /-1080 \mathrm{~m}$ ) decreases to $0.01 \%$. According to group analysis, bitumen contains about $50-60 \%$ oils, $40-45 \%$ resins, and in the lower part of the section the oil content decreases to $15-20 \%$. Oil in the area of the Udachnaya pipe contains less resins $(30-35 \%)$ compared to bitumen, and its asphaltene content does not exceed $4 \%$. The gas content of the field is due to the presence of gases dissolved in oil and brines, however, the rocks themselves have almost no sorption capacity. The gas content of the field was assessed to a depth of $800 \mathrm{~m}$; the main gases are hydrocarbon mixtures with predominant methane content. Petroleum bitumen in kimberlites complicates the ore processing, and their presence in rocks have a great impact on the conduction of blasting operation in the underground conditions;

2. Multiple rock falls were observed both from the roof and from the sides of the workings, this is especially typical for the ore body - kimberlite ores are very easy to flake and crumble, starting their destruction in an extremely short time. Moreover, kimberlites of the East ore body are different from the ones of the West ore body in their characteristics (Balek, Efremov, 2016; Drozdov, 2009).

These phenomena are mostly observed either in the ore body or in zones of increased fracturing and at contacts with the ore body. Kimberlites of the EOB and WOB change the values of all physical and mechanical properties by 1.1-1.6 times with the increase in depth. The average bulk density varies through the blocks in the upper levels of the field (elevation of $+300 \mathrm{~m} /-280 \mathrm{~m}$ ) from 2.34-2.37 to 2.48-2.6 t/m $\mathrm{m}^{3}$, and on "deep" levels (elevation of $-280 \mathrm{~m} /-1080 \mathrm{~m}$ ) - from $2.52-2.62$ to $2.62-2.69 \mathrm{t} / \mathrm{m}^{3}$. In terms of unconfined compressive strength, kimberlites of the EOB and WOB are considered soft $(\sigma=10-35 \mathrm{MPa})$ and very soft $(\sigma=4-10 \mathrm{MPa})$ rocks. Hardness coefficient of the host rocks on the Protodyakonov's scale of hardness ranges from 1 to 8 , and the coefficient of kimberlites varies from 5 to 7 . The lowest values of the hardness coefficient are recorded in crushing zones, less often in zones of hydrothermal changes, and its maximum values coincide with intensely silicified rocks; 


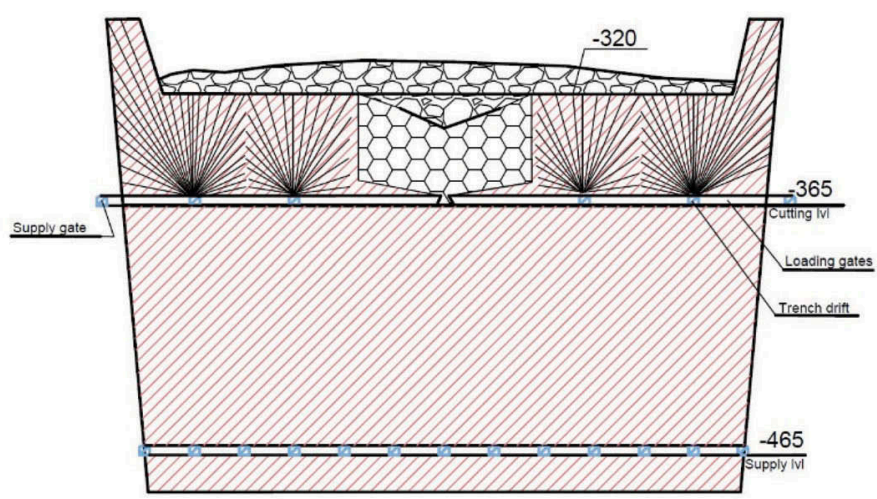

Figure 3. Part of the mining method with the creation of the safety cushion.

3. Increased wear of machinery and equipment associated with the aggressive type of brines, which penetrate underground mines, was observed during the operation of the mine. There have been cases of breakthroughs of brines into the interior of the mine due to the bursting through fractures or disintegration of the underground cavities filled with them (Kovalenko, Tishkov, 2017; Bokiy, Zoteev, Pul, 2019; Sokolov, Smirnov, Antipin, Nikitin, Tishkov, 2018).

Groundwater is represented by calcium chloride brines with an average salinity of 300-400 $\mathrm{g} / \mathrm{l}$. The total gas saturation of brines can reach up to $1.2 \mathrm{~m}^{3} / \mathrm{m}^{3}$. The chemical composition of the aquifer is abnormal: sodium chloride brines have a high content of sodium, sulfates, and bromine. Hydrogen ion concentration $(\mathrm{pH})$ value is 7.75. Filtration properties of kimberlites are variable: water conductivity varies from $1-2$ to $70 \mathrm{~m}^{2} /$ day (average conductivity is $40 \mathrm{~m}^{2} /$ day), however, it always exceeds equivalent parameters of the host rocks. The negative impact of the water inflow in the underground mine will increase with further development of the kimberlite pipe;

4. Numerous safety violations have been recorded since the beginning of the operation of the mine to the present moment, resulting in personnel injuries, including deaths at the mine (according to the regional department of the Russian Ministry of Emergency Situations) The management of the Udachny MPD was faced with the lack of personnel trained to work in the underground conditions of the mine during the period of transition to the underground operation of the enterprise. At the same time, method of combined shrinkage stoping and caving with one-stage stoping and areal ore drawing requires the highest quality of the conducted mining operations and high professionalism of personnel. Moreover, there are no similar mines which use combined shrinkage stoping and caving method among underground mines in the territory of Russian Federation;

5. It is planned to extract mineral resources in the WOB and EOB simultaneously in a descending order by the flow-sheet of the mine. The friable safety cushion is supposed to be gently lowered with the lowering of the mining, conducting work on two levels of the working $-480 \mathrm{~m}$ and $-580 \mathrm{~m}$ (Figure 3). At the same time, the destroyed bottom of the open-pit formed into the ore friable safety cushion should go down, increasing the depth of the pit, as well as forming and exposing the mass of the host rocks located between the East and West ore bodies.

\section{RESULTS}

Mass of the host rocks located between the East and West ore bodies consists of extremely disturbed rocks, especially in the contact zone. The mass at the elevation of $-580 \mathrm{~m}$ is 
comparable in volume with the volume of both ore bodies. It becomes impossible to control the state of the inner-pipe mass as the mining operations deepen. Active processes of flattening of the sides, which gradually come down onto the ore cushion, are already taking place in the pit, further ensuring the inability to safely come to the bottom of the pit and restricting visual observation of the smoothly exposing mass.

The parameters of the safety cushion were calculated by the specialists of the Institute of Mining of Ural Branch of RAS, taking into consideration the collapse of the known volume of the sides with the known geometry and location (Sokolov, Smirnov, Antipin, Nikitin, Tishkov, 2018). However, in the case of uncontrolled destruction of the inner-pipe mass, it is impossible to give an accurate estimation of the volume of collapsed rocks on the safety cushion, including giving a reliable prediction of the height and the place of the collapse. At the same time, if the thickness of the safety cushion is insufficient, there is a real threat of transfer of the impact energy through the safety cushion to the underground mines. This transfer can cause dangerous deformations of the underground mines, up to creating emergency situation at the field.

The results of the analysis of the actual state and development prospects of mining operations in the EOB and WOB indicate that ensuring a cost-effective and safe extraction of reserves of the Udachnaya Pipe is problematic without developing measures to eliminate dangerous geomechanical situations caused by an increase the depth of mining operations. Initial data for predicting such situations can be obtained using the modeling method on models of equivalent materials of large-scale geomechanical processes in block rock masses developed at St. Petersburg Mining University (Zuev B.Yu., Zubov V.P., Smychnik A.D., 2019; Zuev B. Yu., Zubov V. P., Fedorov A. S., 2019). This method allows you to study the stress-strain state of the rock mass located between the EOB and WOB for various stages of development of mining operations, and on this basis to take preventive measures aimed at increasing the efficiency of mining ore bodies.

\section{CONCLUSION}

The current state of the Udachny mine can be called steady and stable. The production capacity required by the engineering design is achievable with the existing mining technology. It is suggested based on the analysis of the geological conditions of the pipe to adjust the parameters of the mining methods as mining operations are deepened to maintain the production volume. There is a steady tendency to the degradation of the mining conditions:

- An increase in the volume of underground brines penetrating into the workings directly affects mining operations, the safety of the underground workings, and the condition of the machinery and equipment;

- The process of destruction of the access crosscut of the bottom of the blocks composed of kimberlite, which will experience high loads, is going to begin after the start of the extraction process using combined shrinkage stoping and caving method. Open access to mine air is going to accelerate the destruction of walls of the workings;

- Geomechanical issues will occur associated with the weakening of the sides of the open-pit and with the violation of the initial state of the rock mass during the mining of the West and East ore bodies. The mass located between the ore bodies is extremely disturbed. There is a possibility of partial relaxation, and fracturing, and sudden uncontrolled collapses of rocks on the safety cushion with a decrease in level of the mining operations and exposure of this rock mass. In case of uncontrolled collapse of the rock mass, there is a possibility of exceeding the maximum allowable stability of the cushion up to serious dynamic impacts on the underlying workings.

These factors, which impact the mining of the kimberlite pipe, require further scientific research. At the same time, the inner-pipe mass requires special attention, including field studies and research operations to identify and prevent dangerous uncontrolled collapses. 


\section{REFERENCES}

Balek A. E., Efremov E. Yu. Justification of the geomechanical conditions of the underground mining of the diamond pipe "Udachnaya pipe". Innovative geotechnologies in the development of ore deposits, 2016, pp. 173-176.

Balek A. E., Sashurin A. D. The problem of assessing the natural stress-strain state of a rock mass during subsurface development. Mining Information and Analytical Bulletin, special issue, 2016, pp. 9-23.

Bokiy I. B, Zoteev O. V, Pul V. V. Analysis of the process of subsidence of the rock pillow during mining of the western ore body of the Udachnaya pipe using a collapse system, Mining Journal, No. 2, 2019, pp. 43-46;

Brief report by independent experts on the reserves and resources of diamond deposits of the ALROSA group of companies, Micon International Co Limited, 2018, http://www.alrosa.ru/wp-content/ uploads/2013/11/Alrosa-Summary-Report-Final-RUS.pdf

Chadwick J., Automated Finsch, International Mining, 2012, pp. 10-13.

Drozdov A.V. Geotechnological problems of developing the deep horizons of the Udachnaya pipe. Subsoil use problems: issues of integrated development of deep-seated mineral deposits, 2009, pp. $110-121$.

Drozdov A.V. Mining and geological features of the deep horizons of the Udachnaya pipe. Mining Information and Analytical Bulletin, No. 1, 2011, pp. 153-165.

Drozdov A.V. Mining, geological and technological problems in the construction of the Udachny underground mine. Mining Information and Analytical Bulletin, No. 2, 2015, pp. 125-131;

Kovalenko A. A., Tishkov M. V. Assessment of the underground method of mining the Udachnaya pipe field using a self-collapsing system. Mining Information and Analytical Bulletin, No. 4, 2017, pp. $117-128$.

Kovalenko. A.A., Tishkov M.V. Evaluation of development of the Udachnaya pipe field. Mining Information and Analytical Bulletin, No. 12, 2016, pp. 173-174

Nikitin I.V. Optimization of opening parameters during underground mining of open-pit reserves of a kimberlite deposit. Topical Issues of Rational Use of Natural Resources, No. 1, 2017, pp. 21-28;

Piven' G.F. Technologies for the development of sub-quarry reserves of the Udachnaya pipe. Notes of the Mining Institute, No. 1, 2011, pp. 359-361.

Sokolov I.V., Smirnov A.A., Antipin Yu.G., Nikitin I.V., Tishkov M.V. Justification of the thickness of the safety cushion when working out the quarry reserves of the Udachnaya pipe with caving systems. Technology mining operations, FTRPRI, No. 2, 2018, pp. 52-62.

The quarterly report of ALROSA PJSC for the 3rd quarter of 2019, ALROSA PJSC, 2019, http://www. alrosa.ru/wp-content/uploads/2019/11/3-квартал-2019-года.pdf.

Trushko V.L., Protosenya A.G., Prospects of geomechanics development in the context of new technological paradigm. Journal of Mining Institute, Vol. 236, 2019, pp. 162-166.

Yakubovskiy M.M., Sankovsky A.A., Drilling and blasting design based on invariable mining parameters. Journal of Industrial Pollution Control, Vol. 33, 2017, pp. 931-936.

Zuev B.Yu., Zubov V. P., Fedorov A. S. Application prospects for models of equivalent materials in studies of geomechanical processes in underground mining of solid. Eurasian mining, No. 1, 2019, pp. $8-12$.

Zuev B.Yu., Zubov V.P., Smychnik A.D. Determination of static and dynamic stresses in physical models of layered and block massifs. Mountain Journal, No. 7, 2019, pp. 61-66. 